\title{
Investigation of antioxidant, antimicrobial and toxicity activities of lichens from high altitude regions of Nepal
}

\author{
Baidya Nath Jha ${ }^{1,2 \dagger}$, Mitesh Shrestha ${ }^{1,2 \dagger}$, Durga Prasad Pandey ${ }^{3}$, Tribikram Bhattarai ${ }^{2}$, Hari Datta Bhattarai ${ }^{1}$ \\ and Babita Paudel ${ }^{1 *}$
}

\begin{abstract}
Background: Several lichen species are reported to be used tradiationally in many theraupatic practices. Many lichen species are reported as sources of several bioactive natural compounds. Several lichen species of Nepal are so far chemically unexplored.

Methods: The morphological, anatomical and phytochemical characteristics of lichens were compared for the taxonomic identification of the species. Methanol- water extract of lichens were sub fractionated into hexane, dichloromethane and methanol fractions for bioactivity assays. Antimicrobial activities of extracts were evaluated agaisnt pathogenic bacteria and fungal species. DPPH test was used for antioxidant potential evaluation.

Brineshrimp test was perfermed to evaluate toxicity of the extracts.

Results: A total of 84 lichen specimens were collected and identified from Annapurna Conservation Area (ACA) Nepal. The specimens were identified as belonging to 19 genera and 47 species. Methanol fractions of 16 specimens and dichloromethane (DCM) fractions of 21 lichens specimens showed antioxidant activities comparable with commercial standards (BHA, Butylated hydroxyanisole, $\mathrm{IC} 50=4.9 \pm 0.9 \mu \mathrm{g} / \mathrm{mL}$ ) even at crude extract level.

Similarly, the DCM fraction of 17 lichens showed potential antimicrobial activity against a Gram-positive bacterium (Staphylococcus aureus KCTC3881) and DCM fractions of 45 lichens showed antimicrobial activity against a Gramnegative bacterium (Klebsiella pneumoniae KCTC2242). DCM fractions of three lichens showed antifungal activity against the yeast, Candida albicans KCTC 7965. Likewise, methanol fractions of 39 lichens and DCM fractions of 74 lichens showed strong toxicity against brine shrimp nauplii with more than $80 \%$ mortality.
\end{abstract}

Conclusion: Such biological activity-rich lichen specimens warrant further research on exploration of natural products with antioxidant, antimicrobial and anti cancer (toxic) potential.

Keywords: Antimicrobial, Antioxidant, DPPH, Lichen, Thin layer chromatography

\section{Background}

Lichens are cosmopolitan in distribution from arctic to tropical regions and from the plains to the highest mountains, and some survive in the extreme environment of deserts. Lichen metabolites of several chemical classes such as - aliphatic acids, pulvinic acid derivatives, depsides and depsidones, dibenzofurans, diterpenes,

\footnotetext{
* Correspondence: paudelb@ribb.org.np

${ }^{\dagger}$ Equal contributors

${ }^{1}$ Research Institute for Bioscience and Biotechnoogy, RIBB, Sinamangal,

Kathmandu, Nepal

Full list of author information is available at the end of the article
}

anthraquinones, naphthoquinones, xanthones, and epidithiopiperazinediones have been described. These compounds have shown a wide range of biological activities such as antibiotic, antimycobacterial, antiviral, antiinflammatory, analgesic, antipyretic, antiproliferative, cytotoxic effects and antioxidant properties [1,2].

Several pathogenic bacteria have developed into multiple drug resistant strains. To overcome such phenomenon, several novel antibacterial compounds need to be developed. A number of lichens have been screened for antibacterial activity [3]. Several lichen 
compounds were found active against Gram-positive bacteria and mycobacteria [4].

Reactive oxygen species (ROS) are harmful for living organisms [5] causing chronic inflammation, which in turn can lead to several diseases including cardiovascular diseases, cancer, age-related disorders, metabolic disorders, and atherosclerosis [6]. ROS react with various cellular components including DNA and ultimately leading to cell inactivation or death [7]. Living organisms accumulate various ROS through both normal metabolic processes and exogenous sources like environmental stresses. Various types of ROS, e.g. hydrogen peroxide $\left(\mathrm{H}_{2} \mathrm{O}_{2}\right)$ are produced inside the living organisms [8]. These ROS are highly reactive and unstable due to the presence of an unpaired electron in their outer shell. The administration of antioxidants can remove or reduce the content of ROS in human body and thereby reduce the negative impacts of ROS in human health. Most of the knowledge on antioxidant activities of lichens and their chemical investigations are derived from the species of tropical and sub-tropical origin. Fewer studies have been conducted on the antioxidant activities of lichens from extreme environments such as the Antarctic regions $[9,10]$ and high altitude region of Nepal [11].

Nepal is a mountainous country which contains diverse geographic locations ranging from $60 \mathrm{~m}$ to $8848 \mathrm{~m}$ above sea level (asl). In Nepal, 465 species of lichens from 79 genera have been recorded, of which 48 species are described as endemic [12]. Because of its unique biogeographic location, altitudinal variation and diverse climatic and topographic conditions, several lichen species can be obtained with in a small geographical area. Traditionally, a variety of lichen species are used to prepare medicines for several diseases [13]. There are very few reports of chemical investigations of lichens species from Nepal [2]. In this report we investigated antioxidant, antibacterial, antifungal and toxic activities of lichens from the Annapurna Conservation Area (ACA) region. The phytochemistry of those specimens is yet to be explored.

\section{Methods}

\section{Collection and identification of lichen species}

A total of eighty four lichen specimens (Table 1) were collected from five different geographical locations of ACA of western Nepal in the time period of Janauary, 2014 to April, 2014. The number of specimens collection per collection site was as follows: Chame (2713 m asl), Danaque (2230 m asl), Jomsom (2760 m asl), Ghandruk (2012 $\mathrm{m}$ asl) and Sarangkot (1750 m asl). All the lichen specimens were identified by analyzing morphological, anatomical and phytochemical characteristics using a lichen identification check list [14]. Among others, twenty two specimens were identified up to genus level only. Voucher specimens of the lichen are deposited in the lichen herbarium of the Research Institute of Bioscience and Biotechnology, Kathmandu, Nepal.

\section{Extraction}

Completely freeze-dried and ground lichen samples, 1$10 \mathrm{~g}$ (Table 1) were extracted in a mixture of methanol and water $(90: 10 \mathrm{v} / \mathrm{v})$. Then, the extracts were filtered and solvent was evaporated at $38{ }^{\circ} \mathrm{C}$ under vacuum. This extraction procedure was repeated three times to ensure the complete extraction of extractable compounds. The total extract of a specimen was dissolved in distilled water $(100 \mathrm{~mL})$ and washed with hexane $(300 \mathrm{~mL})$ three times to remove pigments and fats. The water phase of extract was further washed with dichloromethane (300 mL) (DCM) thrice to remove medium polar compounds. The remaining water phase was freeze-dried, and residue dissolved in methanol. Insoluble parts of sugar and polysaccharides were removed. The DCM and methanol fractions of the extracts were then lyophilized and stored at $-20{ }^{\circ} \mathrm{C}$ until further use.

\section{Chemical reagents}

2, 2-Diphenyl-1-picrylhydrazyl (DPPH), Butylated hydroxyanisole (BHA), Ampicillin, Amphotericin B and Berberine chloride were purchased from Sigma-Aldrich, USA. All chemicals and reagents were of analytical grade. The solvents used during extraction and chromatography were of normal grade quality and they were distilled before use. The bacterial culture media, nutrient agar (NA) and Nutrient Broth (NB) and the fungal growth medium, Potato dextrose medium (PDA) were purchased from Difco, USA.

\section{Antimicrobial assay}

\section{Target microorganisms and culture condition}

Three clinical microorganisms, including one Grampositive Staphylococcus aureus KCTC3881) and one Gram-negative (Klebsiella pneumoniae KCTC2242) bacteria and a fungus, Candida albicans KCTC 7965, were purchased from Korean Collection of Type Culture (KCTC). Bacterial strains were grown on NA at $37{ }^{\circ} \mathrm{C}$ and C. albicans was grown on PDA at $25^{\circ} \mathrm{C}$.

\section{Disk diffusion assay}

Antimicrobial testing was carried out by using a previously described paper disk assay [11]. Sterile paper disks (Adventic, Japan) of $6 \mathrm{~mm}$ size were loaded with lichen extract at a concentration of $2 \mathrm{mg} /$ disk in triplicate and allowed to dry at room temperature under sterile conditions. The disks were kept on the surface of NA (Nutrient agar) or PDA (Potato dextrose agar) plates, which had been freshly swabbed with the overnight 
Table 1 Lichens collected from Annapurna conservation area and their biological activities

\begin{tabular}{|c|c|c|c|c|c|c|c|c|c|}
\hline \multirow[t]{2}{*}{ S.N } & \multirow[t]{2}{*}{ Symbol } & \multirow[t]{2}{*}{ Name } & \multirow[t]{2}{*}{ Dry wt. } & \multicolumn{2}{|c|}{ Activity $\mathrm{DPPH}^{\mathrm{a}}$} & \multirow{2}{*}{$\begin{array}{l}\text { Anti microbial activity } \\
\text { DCM }\end{array}$} & \multicolumn{2}{|c|}{ Brine shrimp } & \multirow{2}{*}{$\begin{array}{l}\text { Candida albicans }(\mathrm{mm}) \\
\text { DCM fraction }\end{array}$} \\
\hline & & & & Methanol & DCM & & $\overline{\mathrm{MeOH}}$ & $\overline{D C M}$ & \\
\hline 1 & DAN-1 & Parmotrema cetratum & 10 & $44.4 \pm 0.5$ & $11.4 \pm 0.1$ & $A(7) B(7)$ & S & S & - \\
\hline 2 & DAN-2 & Usnea pectinata & 10 & - & - & - & S & S & - \\
\hline 3 & DAN-3 & Ramalina conduplicans & 10 & - & $22.9 \pm 0.7$ & $B(12)$ & S & S & - \\
\hline 4 & DAN-4 & Everniastrum cirrhatum & 2 & - & - & $B(11)$ & । & S & - \\
\hline 5 & DAN-5 & Parmotrema sanoti-angelii & 10 & - & - & $A(10) B(10)$ & s & S & - \\
\hline 6 & DAN-6 & Parmotrema reticulatum & 10 & $23.3 \pm 0.3$ & $22.1 \pm 0.1$ & $A(10) B(9)$ & S & S & - \\
\hline 7 & DAN-7 & Heterodermia diademata & 10 & - & - & $\mathrm{B}(7)$ & । & S & - \\
\hline 8 & DAN-8 & Cladonia verticillata & 9.1 & - & $44.1 \pm 0.3$ & B (8) & W & $S$ & - \\
\hline 9 & DAN-9 & Parmotrema sp. & 10 & - & - & $\mathrm{B}(7)$ & । & S & - \\
\hline 10 & DAN-10 & Parmotrema tinctorum & 10 & - & - & $B(7)$ & । & S & - \\
\hline 11 & DAN-11 & Peltigera polydactyla & 3.6 & $11.3 \pm 0.2$ & $19.6 \pm 0.1$ & - & । & S & - \\
\hline 12 & JOM-1 & Lobaria retigera & 10 & - & - & - & S & S & - \\
\hline 13 & $\mathrm{JOM}-2$ & Parmotrema thomsonii & 10 & - & - & $A(8) B(11)$ & S & $S$ & - \\
\hline 14 & $\mathrm{JOM}-3$ & Ramalina sp. & 10 & - & - & - & S & s & - \\
\hline 15 & $\mathrm{JOM}-4$ & Everniastrum cirrhatum & 10 & - & - & $B(14)$ & S & S & - \\
\hline 16 & $\mathrm{JOM}-5$ & Usnea sp. & 10 & - & - & $B(10)$ & S & $\mathrm{S}$ & - \\
\hline 17 & JOM -6 & Peltigera polydactyla & 9.2 & $11.2 \pm 0.1$ & - & - & S & S & - \\
\hline 18 & $\mathrm{JOM}-7$ & Heterodermia diademata & 10 & - & - & - & । & S & 12 \\
\hline 19 & $\mathrm{JOM}-8$ & Parmotrema tinctorum & 10 & - & - & $A(11) B(7)$ & S & S & - \\
\hline 20 & JOM -9 & Leptogium delavayi & 10 & - & - & - & W & । & - \\
\hline 21 & JOM -10 & Parmotrema reticulatum & 5.9 & - & - & - & S & । & - \\
\hline 22 & JOM -11 & Parmelina quercina & 5.6 & - & - & $B(10)$ & । & $S$ & - \\
\hline 23 & JOM -12 & Cladonia squamosa & 10 & - & - & $A(12) B(13)$ & । & S & - \\
\hline 24 & JOM -13 & Parmotrema sp. & 10 & - & - & $\mathrm{A}(11) \mathrm{B}(7)$ & s & $S$ & 14 \\
\hline 25 & JOM -14 & Heterodermia indica & 2.8 & - & $49.9 \pm 2.4$ & $A(9) B(8)$ & । & S & 11 \\
\hline 26 & JOM -15 & Heterodermia leucomela & 3.8 & - & $47.7 \pm 0.5$ & $A(8) B(9)$ & । & s & - \\
\hline 27 & JOM -16 & Leptogium delavayi & 0.9 & - & $47.1 \pm 1.8$ & - & । & W & - \\
\hline 28 & $\mathrm{CHA}-1$ & Ramalina roesleri & 10 & - & $20.2 \pm 0.2$ & - & । & s & - \\
\hline 29 & $\mathrm{CHA}-2$ & Parmotrema sp. & 10 & - & - & - & S & I & - \\
\hline 30 & $\mathrm{CHA}-3$ & Parmotrema sp. & 10 & - & - & - & S & $S$ & - \\
\hline 31 & $\mathrm{CHA}-4$ & Leptogium sp. & 0.8 & - & - & - & । & S & - \\
\hline 32 & $\mathrm{CHA}-5$ & Cladonia verticillata & 10 & - & - & - & । & S & - \\
\hline 33 & $\mathrm{CHA}-6$ & Usnea sp. & 9 & - & - & - & S & S & - \\
\hline 34 & $\mathrm{CHA}-7$ & Lepraria sp. & 6.8 & - & - & - & S & । & - \\
\hline 35 & $\mathrm{CHA}-8$ & Peltigera polydactyla & 10 & $5.7 \pm 0.02$ & $5.56 \pm 0.2$ & - & । & $S$ & - \\
\hline 36 & $\mathrm{CHA}-9$ & Lepraria sp. & 10 & - & - & - & । & W & - \\
\hline 37 & GHAN-1 & Coccocarpia erythroxyli & 3.4 & - & - & - & । & I & - \\
\hline 38 & GHAN-2 & Parmotrema melanothrix & 10 & - & - & $B(7)$ & s & $S$ & - \\
\hline 39 & GHAN-3 & Heterodermia diademata & 10 & - & - & $B(7)$ & W & $S$ & - \\
\hline 40 & GHAN-4 & Parmotrema praesorediosum & 10 & - & - & $B(9)$ & । & $S$ & - \\
\hline 41 & GHAN-5 & Pertusaria leucosora & 10 & $22.4 \pm 0.9$ & $44.6 \pm 1.0$ & $B(13)$ & S & S & - \\
\hline 42 & GHAN-6 & Cladonia sp. & 10 & - & - & $B(9)$ & । & S & - \\
\hline
\end{tabular}


Table 1 Lichens collected from Annapurna conservation area and their biological activities (Continued)

\begin{tabular}{|c|c|c|c|c|c|c|c|c|c|}
\hline 43 & GHAN-7 & Heterodermia diademata & 10 & - & - & - & $S$ & $S$ & - \\
\hline 44 & GHAN-8 & Heterodermia punctifera & 10 & $43.9 \pm 2.1$ & $47.3 \pm 0.6$ & - & $S$ & S & - \\
\hline 45 & GHAN-9 & Parmotrema sp. & 3 & $22.8 \pm 0.9$ & - & $B(12)$ & W & S & - \\
\hline 46 & GHAN-10 & Leptogium delavayi & 8.5 & - & - & - & W & I & - \\
\hline 47 & GHAN-11 & Lecidea sp. & 10 & - & - & $B(12)$ & $S$ & $\mathrm{~S}$ & - \\
\hline 48 & GHAN-12 & Parmelia sp. & 10 & - & - & $B(9)$ & S & S & - \\
\hline 49 & GHAN-13 & Parmotrema sp. & 10 & $19.9 \pm 3.0$ & - & $B(11)$ & । & $S$ & - \\
\hline 50 & GHAN-14 & Collema sp. & 1.7 & - & - & - & 1 & 1 & - \\
\hline 51 & GHAN-15 & Heterodermia microphylla & 10 & - & $23.7 \pm 0.1$ & - & । & $S$ & - \\
\hline 52 & GHAN-16 & Parmelia meiophora & 6.9 & - & - & $B(15)$ & S & S & - \\
\hline 53 & GHAN-17 & Usnea baileyi & 1.8 & - & - & - & $S$ & $S$ & - \\
\hline 54 & GHAN-18 & Heterodermia leucomelos & 10 & - & - & $A(7) B(7)$ & । & $\mathrm{S}$ & - \\
\hline 55 & GHAN-19 & Parmotrema sp. & 10 & - & - & $B(11)$ & $S$ & $S$ & - \\
\hline 56 & GHAN-20 & Pannaria complanata & 10 & - & - & $A(11) B(10)$ & S & S & - \\
\hline 57 & GHAN-21 & Hypotrachyna flexilis & 10 & - & - & $B(9)$ & । & S & - \\
\hline 58 & SAR-1 & Heterodermia indica & 7.8 & $21.2 \pm 0.3$ & $24.0 \pm 0.1$ & $B(8)$ & $S$ & S & - \\
\hline 59 & SAR-2 & Parmotrema reticulatum & 10 & - & - & $B(9)$ & $S$ & $S$ & - \\
\hline 60 & SAR-3 & Heterodermia punctifera & 7.83 & - & - & - & I & S & - \\
\hline 61 & SAR-4 & Usnea coralline & 9.6 & - & - & - & $\mathrm{S}$ & $\mathrm{S}$ & - \\
\hline 62 & SAR-5 & Ramalina conduplicate & 5.3 & - & $49.0 \pm 2.3$ & $B(12)$ & S & S & - \\
\hline 63 & SAR-6 & Lobaria disecta & 10 & - & $50.7 \pm 2.2$ & $B(7)$ & W & $S$ & - \\
\hline 64 & SAR-7 & Parmotrema reticulatum & 10 & - & - & $B(7)$ & W & S & - \\
\hline 65 & SAR-8 & Heterodermia podocarpa & 10 & - & - & $B(12)$ & W & $S$ & - \\
\hline 66 & SAR-9 & Parmelaria thomsonii & 10 & $87.3 \pm 7.1$ & - & $B(10)$ & W & S & - \\
\hline 67 & SAR-10 & Everniastrum nepalenses & 10 & - & - & $B(8)$ & $S$ & $S$ & - \\
\hline 68 & SAR-11 & Cladonia coccifera & 10 & $23.5 \pm 0.8$ & - & - & । & S & - \\
\hline 69 & SAR-12 & Parmotrema reticulatum & 5.7 & - & $53.1 \pm 6.9$ & - & S & S & - \\
\hline 70 & SAR-13 & Parmotrema sp. & 10 & $47.8 \pm 1.3$ & - & $A(9)$ & $S$ & S & - \\
\hline 71 & SAR-14 & Parmelia omphalodes & 10 & - & - & $A(10) B(11)$ & । & S & - \\
\hline 72 & SAR-15 & Parmotrema reticulatum & 3.5 & $49.8 \pm 0.1$ & - & $B(9)$ & M & $S$ & - \\
\hline 73 & SAR-16 & Parmotrema sp. & 1.5 & - & - & $B(8)$ & S & S & - \\
\hline 74 & SAR-17 & Heterodermia speciosa & 6 & - & - & $A(7)$ & M & S & - \\
\hline 75 & SAR-18 & Parmotrema sp. & 8.6 & $49.9 \pm 0.3$ & - & - & S & $\mathrm{S}$ & - \\
\hline 76 & SAR-19 & Parmotrema sp. & 8.4 & - & - & $A(9)$ & S & S & - \\
\hline 77 & SAR-20 & Heterodermia microphylla & 10 & - & - & $A(8)$ & W & S & - \\
\hline 78 & SAR-21 & Heterodermia microphylla & 7.3 & - & - & - & । & । & - \\
\hline 79 & SAR-22 & Parmelia omphalodes & 10 & - & - & - & S & S & - \\
\hline 80 & SAR-23 & Heterodermia microphylla & 6.4 & - & $24.1 \pm 0.4$ & - & W & $S$ & - \\
\hline 81 & SAR-24 & Heterodermia microphylla & 1.2 & - & $45.8 \pm 1.1$ & $A(9)$ & I & S & - \\
\hline 82 & SAR-25 & Cladonia coccifera & 0.6 & - & $47.9 \pm 0.2$ & - & । & S & - \\
\hline 83 & SAR-26 & Heterodermia speciosa & 1.4 & - & $46.7 \pm 1.3$ & $B(13)$ & । & S & - \\
\hline \multirow[t]{3}{*}{84} & SAR-27 & Pertusaria sp. & 0.4 & $49.3 \pm 2.6$ & - & $B(12)$ & । & $S$ & - \\
\hline & & $\mathrm{BHA}$ & & $5.0 \pm 0.4$ & & & & & \\
\hline & & Ampicillin(10 $\mu \mathrm{g})$ & & & & $A(20), B(19)$ & & & \\
\hline
\end{tabular}


Table 1 Lichens collected from Annapurna conservation area and their biological activities (Continued)

$\begin{array}{ll}\text { Amphotericin } B(10 \mu \mathrm{g}) & \mathrm{W} \\ \text { Berberine chloride }(8 \mu \mathrm{g}) & \mathrm{M} \\ \text { Berberine chloride }(12 \mu \mathrm{g}) & \mathrm{S} \\ \text { Berberine chloride }(16 \mu \mathrm{g}) & \end{array}$

${ }^{\mathrm{a}} \mathrm{C}_{50}(50 \%$ inhibition in DPPH color) data, A-antibacterial active against Staphylococcus aureus (inhibition zone in mm), B-antibacterial activity against Klebsiella pneumoniae (inhibition zone in $\mathrm{mm}$ ), S-strong activity (more than $80 \%$ death of brine shrimp), M-Moderate( $50 \%-80 \%$ of death of brine shrimp), W-Weak (less than $50 \%$ of death of brine shrimp), l-inactive (no death at all)

grown broth culture of the target microbial strains. Then, the plates were incubated at optimum growth temperature of each strain for 24-48 h. The zones of inhibition around the lichen extract loaded paper disks were reflective of the antimicrobial effectiveness of the extract. Paper disks loaded with methanol, the solvent used to dissolve crude extract, were used as negative controls and the paper disks loaded with Ampicillin and Amphotericin B were used as positive controls for bacteria and yeast respectively.

\section{Antioxidant assay}

DPPH free radical scavenging assay Free radical scavenging activity for the lichen extracts was estimated by using a previously described method [15]. One $\mathrm{mL}$ of $\mathrm{DPPH}$ solution (0.1 $\mathrm{mM}$ of DPPH in methanol) was mixed with $3 \mathrm{~mL}$ of various concentrations of the test extract. The mixture was incubated at room temperature (RT) for $30 \mathrm{~min}$ and the absorbance was measured at $517 \mathrm{~nm}$ in a UV-Visible spectrophotometer (SCINCO). Reaction mixtures without the test extract and with (Butylated hydroxyanisole) BHA were used as negative and positive controls, respectively. The experiment was conducted in triplicate.

Brine shrimp lethality test Brine shrimp lethality test (BST) was used to evaluate the toxicity of various lichen's crude extracts [16] with slight modification. The eggs of Artemia salina were hatched in aerated seawater in light at $25{ }^{\circ} \mathrm{C}$. The hatched active nauplii were attracted towards the direction of light. The active nauplii (about 100) were selected and treated with $1 \mathrm{mg} / \mathrm{mL}$ of the test samples in 24 well plates. The effects of the test samples were monitored after $24 \mathrm{~h}$ of treatment by observing the live nauplii. The mortality rate of the nauplii indicated the toxicity of the test samples. The activity was categorized into four groups-strong $(80 \%$ to $100 \%$ death of nauplii), moderate $(50 \%$ to $80 \%$ death of nauplii), weak (less than $50 \%$ death of nauplii) and inactive (no death at all) (Table 1). Berberine chloride was used as positive control and sea water was used as negative control.
TLC based antioxidant activity screening of lichen extracts Thin layer chromatography analysis of all lichen extracts was performed by using analytical silica gel TLC plates (Merck). An aliquot of 200 microgram lichen extract was loaded in the bottom of TLC plates (size. $10 \mathrm{~cm} \mathrm{X} 20 \mathrm{~cm}$ ) and run on the mobile phase of $10 \%$ methanol in DCM. The plates were observed under UVs $(254 \mathrm{~nm}$ and $365 \mathrm{~nm}$ ) to observe the bands of separated compounds. The plates were sprayed with DPPH solution $(4 \mathrm{mM})$ in methanol. The yellow color developed against purple surface background of DPPH indicated antioxidant active compounds in the extracts.

Data analysis All data were expressed as mean \pm SD from a minimum of three replicates. 50\% Inhibition concentration $\left(\mathrm{IC}_{50}\right)$ was calculated by using Microsoft Excel 2007.

\section{Results and discussion \\ Collection and identification of lichens}

A total of 84 lichen specimens comprising 19 genera and 47 species were collected from five different locations of ACA starting from the altitude of $1750 \mathrm{~m}$ asl to $2760 \mathrm{~m}$ asl.

\section{Antioxidant activity}

In this experiment, in-vitro antioxidant assays based on electron transfer (ET) or hydrogen atom transfer (HAT) system- DPPH free radical was used to investigate the antioxidant activity of lichen extracts. ET-based assays measured the capacity of an antioxidant which reduces an oxidant by changing the color [15]. Thus, the degree of color change was correlated with antioxidant potential.

$\mathrm{DPPH}$ is commercially available stable free radical in aqueous or methanol solution and becomes a stable molecule by accepting an electron or hydrogen radical from antioxidant compounds [15]. All the tested lichen extracts and the commercial standard (BHA) exhibited $\mathrm{DPPH}$ free radical scavenging capacity in the concentration dependent manner. $\mathrm{BHA}$ is a strong commercial antioxidant agent and the $\mathrm{IC}_{50}$ of this compound was determined as $4.98 \pm 0.4 \mu \mathrm{g} / \mathrm{mL}$. 
In the present experiment, the test lichens extract showed the varying strengths to scavenge $\mathrm{DPPH}$ free radical. Overall, the $\mathrm{IC}_{50}$ of $\mathrm{DPPH}$ free radical scavenging capacity of active lichens extract was found between $5.6 \pm 0.2$ to $87.3 \pm 7.1 \mu \mathrm{g} / \mathrm{mL}$ (Table 1 ). The Table 1 shows that only 30 specimens' extract possessed antioxidant activities. Among them, the DCM fractions of Parmoterma centratum, Peltigera polydactyla and Ramalina roesleri and methanol fractions of Peltigera polydactyla and Parmoterma sp. showed comparatively strong DPPH reducing activity. The methanol extract of Parmoterma sp. from Nepal origin showed stronger antioxidant activity $\left(\mathrm{IC}_{50}, 11.4 \pm 0.1 \mu \mathrm{g} / \mathrm{ml}\right)$ than the same species collected from Malaysia $\left(\mathrm{IC}_{50},>500 \mu \mathrm{g} / \mathrm{ml}\right)$ [17]. Ramalina bourgeana Mont. ex Nyl. (Ramalinaceae) is consumed as a folk medicine for diuretic and stone-dissolving properties [18]. In the present experiment the data showed that 16 specimens' methanol fraction, 21 specimens' DCM fraction, 7 specimens' both methanol and DCM fractions, 9 specimens' only methanol fractions and 14 specimens' only DCM fractions were antioxidant active. The results indicated the variability of antioxidant compounds in the lichen extracts.

\section{Antimicrobial activities}

Only DCM fraction of the lichen extracts were active against $S$. aureus and $K$. pneumoniae. The sizes of zone of inhibition of active fractions are given in Table 1. Seventeen extracts showed activities against $S$. aureus and 45 extracts showed activities against $K$. pneumoniae. Twelve extracts showed antibacterial activities against both $S$. aureus and $K$. pneumoniae. Thus, the test lichens were found to be antimicrobial active against both Gram-positive and Gram-negative bacterial strains. Only three specimens' extract were active against $C$. albicans. The comparative study of obtained results (Table. 1) showed that the antimicrobial constituents in the lichens extracts were different.

\section{Toxicity against brine shrimp (Artemia salina)}

Hundred percent of Artemia nauplii were alive after $24 \mathrm{~h}$ of experiment in the negative control. $\mathrm{LC}_{50}$ of positive control sample was obtained as $8.4 \mu \mathrm{g} / \mathrm{mL}$. Interestingly, majority of the lichens extracts showed toxicity against Brine shrimp nauplii (Table 1). Four categories of activities have been observed: (S) strong-100-80\% death of nauplii, (M) moderate-80-50\% death of nauplii,
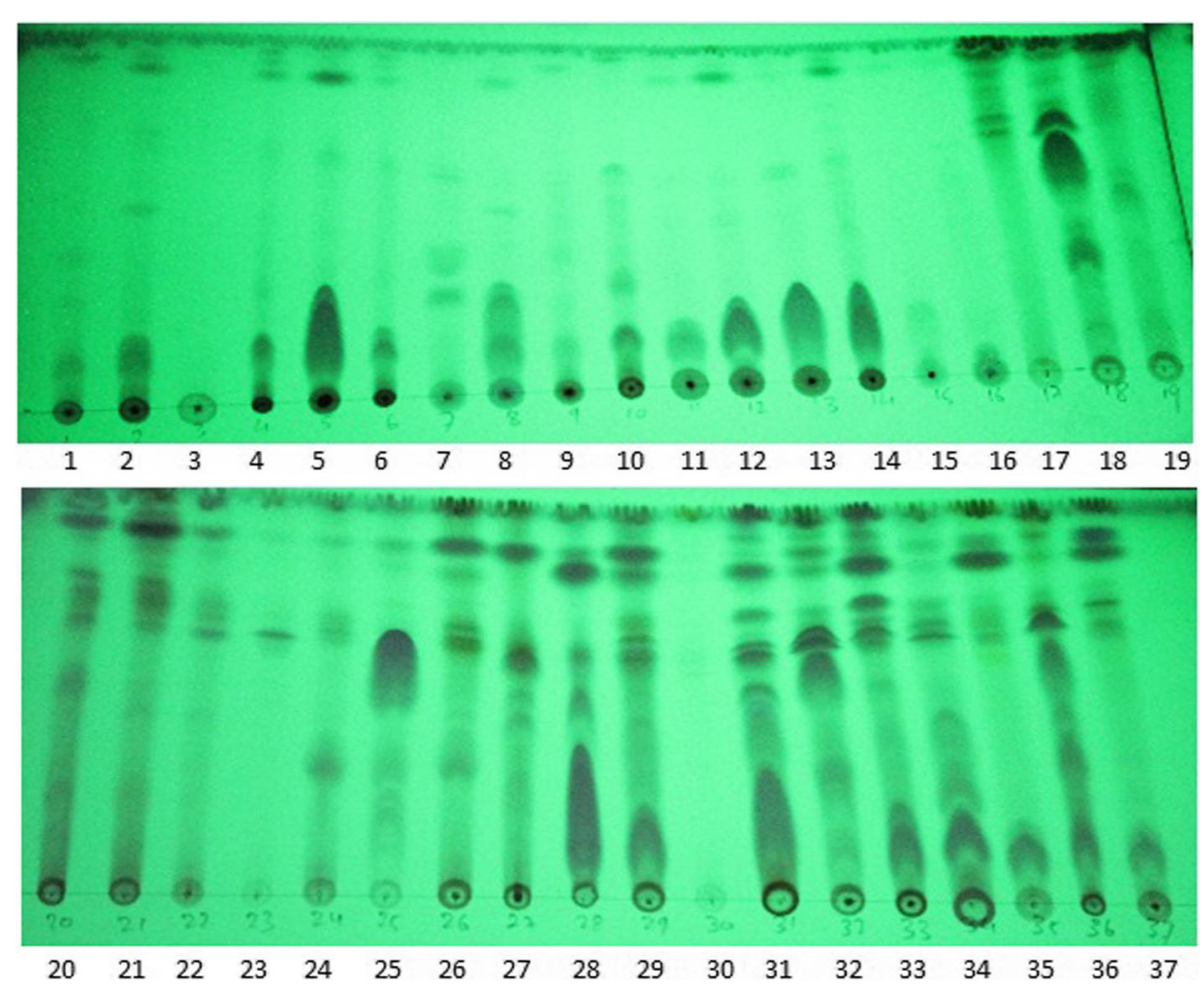

Fig. 1 TLC based chemical screening of lichen extracts. Plate viewed under UV (254 nm). Mobile phase for TLC development was $10 \%$ methanol in DCM. W-methanol soluble water fraction, D-DCM fractions. The sample in the TLC plate is as follows: 1, SAR1W; 2, SAR9W; 3, SAR11W; 4, SAR13W; 5, SAR15W; 6, SAR18W; 7, SAR27W; 8, GHAN5W; 9, GHAN8W; 10, GHAN9W; 11, GHAN13W; 12, JOM6W; 13, DAN1W; 14, DAN6W; 15, DAN11W; 16, CHA8W; 17, SAR1D; 18, SAR5D; 19, SAR6D; 20, SAR12D; 21, SAR23D; 22, SAR24D; 23, SAR25D; 24, SAR26D; 25, GHAN5D; 26, GHAN8D; 27, GHAN15D; 28, JOM14D; 29, JOM15D; 23, JOM16D; 31, DAN1D; 32, DAN3D; 33, DAN6D; 34, DAN8D; 35, DAN11D; 36, CHA1D; 37 CHA8D 
(W) weak-less than $50 \%$ death and (I) inactive-no death of brine shrimp nauplii after $24 \mathrm{~h}$ of incubation. DCM fractions were found to be more toxic than methanol fractions. Strong activities were shown by 74 DCM fractions and 39 methanol fractions while 8 DCM fractions and 32 methanol fractions did not show any activity against $A$. salina nauplii. The lichen extracts of ACA region showed stronger toxicity against $A$. salina than the species of other region [11].

\section{TLC based antioxidant activity screening of lichen extracts}

TLC based chemical screening of the bioactive fractions of the lichens showed a number of bioactive compounds contained in the extracts. As expected, compounds from methanol fractions had a lower Rf value than those from the DCM fraction in this TLC system, which indicates that they were more polar (Fig. 1). TLC based phytochemical screening was performed only for the extracts which showed antioxidant and antimicrobial activities.
The number of antioxidant active bands in methanol fractions is comparatively small than in DCM fractions (Fig. 2). But, the intensity of color change of sprayed $\mathrm{DPPH}$ was much higher in the bands obtained from the methanol fractions than from the DCM fractions. The results indicated that water fractions contained stronger antioxidant compounds than the DCM fractions. The results also indicated that the DCM fractions contained higher number of moderately active antioxidants than the methanol fractions.

\section{Conclusion}

A total of 84 lichen specimens including 19 genera and 47 species were collected and tested for antioxidant, antibacterial, antifungal and toxic properties against Brine shrimp nauplii. The test extract showed potent antioxidant activities. Methanol fractions were found to contain strong antioxidant compounds than DCM fractions as indicated in strong spots in TLC analysis plate after DPPH spray. The TLC analysis also indicated that DCM fractions contained the
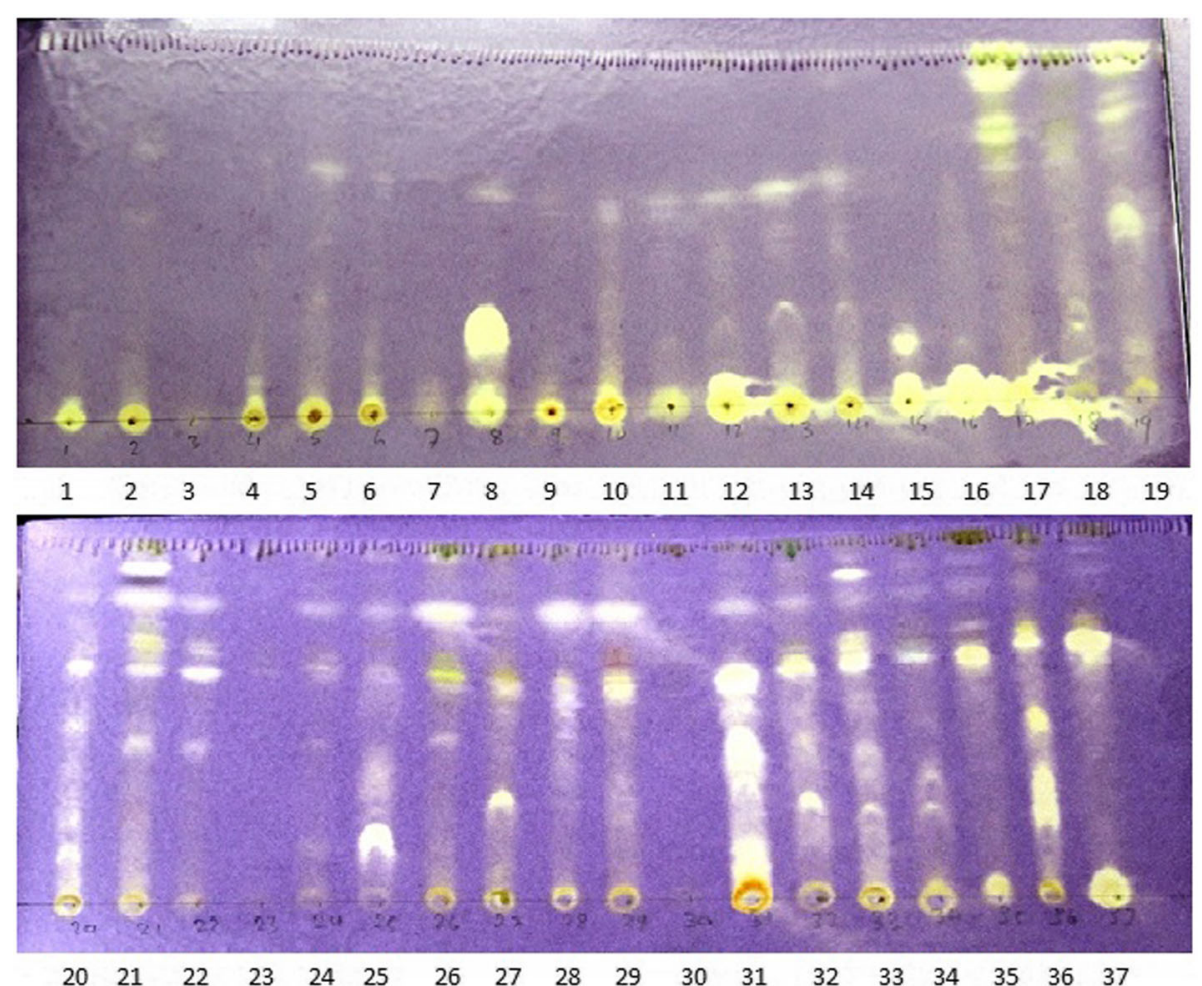

Fig. 2 TLC based antioxidant screening of the active extracts. Mobile phase for TLC development was 10\% methanol in DCM. The purple color was from DPPH and antioxidant active fractions showed reduced in purple color to yellow. The darkness of color spots indicated the potential of antioxidant activity, the size of color spot indicated the content of antioxidant active compounds in the extracts. W- methanol soluble water fraction, D- DCM fractions of lichen extracts. The sample in the TLC plate is as follows:1, SAR1W; 2, SAR9W; 3, SAR11W; 4, SAR13W; 5, SAR15W; 6, SAR18W; 7, SAR27W; 8, GHAN5W; 9, GHAN8W; 10, GHAN9W; 11, GHAN13W; 12, JOM6W; 13, DAN1W; 14, DAN6W; 15, DAN11W; 16, CHA8W; 17, SAR1D; 18, SAR5D; 19, SAR6D; 20, SAR12D; 21, SAR23D; 22, SAR24D; 23, SAR25D; 24, SAR26D; 25, GHAN5D; 26, GHAN8D; 27, GHAN15D; 28, JOM14D; 29, JOM15D; 23, JOM16D; 31, DAN1D; 32, DAN3D; 33, DAN6D; 34, DAN8D; 35, DAN11D; 36, CHA1D; 37, CHA8D 
bigger number of antioxidant compounds. Similarly, several lichen specimens were found antibacterial active against the Gram-negative test strain $K$. pneumoniae. Most of the lichen extracts were found toxic against Brine shrimp nauplii. The results indicated that the lichens from Annapurna conservation area (ACA) warrant further research of isolation and characterization of active compounds.

\section{Abbreviations}

ACA: Annapurna conservation area; ASL: Above sea level; BHA: Butylated hydroxyanisole; DCM: Dichloromethane; DPPH: 2,2-Diphenyl-1-picrylhydrazyl;"

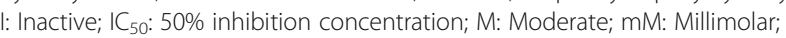
NA: Nutrient agar; NB: Nutrient broth; PDA: Potato dextrose agar; S: Strong; TLC: Thin layer chromatography; UV: Ultraviolet; W: Weak

\section{Acknowledgements}

The research is financially supported by IFS Grant Number: F5476-1 to Dr. Babita Paudel-Bhattarai at Research Institute for Bioscience and Biotechnology, RIBB, Kathmandu,Nepal. The authors are also thankful to Dr. C.B Baniya, Associate Professor, Central Department of Botany, Tribhuvan University, Kathmandu, Nepal for supporting in taxonomic identifications of lichens.

\section{Availability of data and materials}

All the data supporting our findings are contained within the manuscript

\section{Authors' contributions}

BNS and MS: Experiment, field visit, sample collection, DPP and TB: Experiment guidance and critical review of the manuscript, HDB and BP: conception and design of the study, manuscript writing, data analysis and interpretation. All authors read and approved the final manuscript.

\section{Competing interests}

The authors declare that they have no competing interests.

\section{Consent for publication}

Not applicable.

\section{Ethics approval and consent to participate}

Not applicable.

\section{Publisher's Note}

Springer Nature remains neutral with regard to jurisdictional claims in published maps and institutional affiliations.

\section{Author details}

${ }^{1}$ Research Institute for Bioscience and Biotechnoogy, RIBB, Sinamangal, Kathmandu, Nepal. ${ }^{2}$ Central Department of Biotechnology, Tribhuvan University, Kirtipur, Kathamndu, Nepal. ${ }^{3}$ Research Center for Applied Science and Technology, Tribhuvan University, Kirtipur, Kathmandu, Nepal.

Received: 24 January 2017 Accepted: 16 May 2017

Published online: 25 May 2017

\section{References}

1. Ingólfdóttir K. Molecules of interest usnic acid. Phytochemistry. 2002;61:729-36.

2. Kumar KCS, Müller K. Lichen metabolites. 1. Inhibitory action against leukotriene $\mathrm{B}_{4}$ biosynthesis by a non-redox mechanism. J Nat Prod. 1999;62:817-20

3. Vartia KO. In: Ahmadjian V, Hale ME, editors. Antibiotics in lichens, The lichens. New York: Academic Press; 1973. p. 547-61.

4. Ingólfdóttir K, Hijalmarsdóttir MA, Sigurdsson A, Gudjónsdóttir GA Brynjólfsdóttir A, Steingrimssoon O. In vitro susceptibility of Helicobacter pylori to protolichesterinic acid form the lichen Cetraria islandica. Antimicrob Agents Chemother. 1997;41:215-7.

5. Davies K. Oxidative stress: the paradox of aerobic life. Biochemical Society Symposia. 1995;61:1-31.
6. Ames BN, Shigenaga MK, Hagen TM. Oxidants, antioxidants and the degenerative diseases of aging. Proc Natl Acad Sci U S A. 1993;90:7915-22.

7. Dean RT, Davies MJ. Reactive species and their accumulation on radical damaged proteins. Trends Biochem Sci. 1993:18:437-41.

8. Valko M, Leibfritz D, Moncol J, Cronin M, Mazur M, Telser J. Free radicals and antioxidants in normal physiological functions and human disease. International J Biochem Cell Biol. 2007;39:44-84.

9. Bhattarai HD, Paudel B, Hong SG, Lee HK, Yim JH. Thin layer chromatography analysis of antioxidant constituents of lichens from Antarctica. J Nat Med. 2008;62:481-4.

10. Paudel B, Bhattarai HD, Lee JS, Hong SG, Shin HW, Yim JH. Antioxidant activity of polar lichens from king George island (Antarctica). Polar Biol. 2008;31:605-8

11. Paudel B, Bhattarai HD, Pandey DP, Hur JS, Hong SG, Kim IC, et al. Antioxidant, antibacterial activity and brine shrimp toxicity test of some mountainous lichens from Nepal. Biol Res. 2012;45:387-91.

12. BBP (Biodiversity Profile Project). Enumeration of the Lichens of Nepal, HMG Nepal and Government of Netherlands, Kathmandu, Nepal; 1995. p. 1-70.

13. Richardson DHS. Vanishing Lichens, Their history, biology and importance. New York: HafnerPress; 1975. p. 231.

14. Awasti DD. A compendium of the macrolichens from India. Nepal and Srilanka: Dehra Dun; 2007.

15. Blois MS. Antioxidant determinations by the use of a stable free radical. Nature. 1958;26:1199-200.

16. Meyer BN, Ferrign RN, Putnam JE, Jacobson LB, Nicholas DE, McLaughlin JL. Brine shrimp: a convenient general bioassay for active plant constituents. Planta Med. 1982;45:31-4.

17. Rajan VP, Gunasekharan S, Ramanathan S, Murugaiyah V, Samsudin MW, Din LB. Biological activities of four Parmoterma sp. of Malaysian origin and their chemical constituents. JAPS. 2016;6:36-43.

18. González-Tejero MR, Martínez-Lirola MJ, Casares-Porcel M, Molero-Mesa J. Three lichen used in popular medicine in eastern Andalucia (Spain). Econ Bot. 1995:49(1):96-8.
Submit your next manuscript to BioMed Central and we will help you at every step:

- We accept pre-submission inquiries

- Our selector tool helps you to find the most relevant journal

- We provide round the clock customer support

- Convenient online submission

- Thorough peer review

- Inclusion in PubMed and all major indexing services

- Maximum visibility for your research

Submit your manuscript at www.biomedcentral.com/submit
Biomed Central 